\title{
Long-term ocular hypotensive effect of levobunolol: results of a one-year study
}

\author{
MANUEL OBER,' ARMIN SCHARRER,' ROBERT DAVID, \\ BEN-ZION BIEDNER, ${ }^{2}$ GARY D NOVACK, ${ }^{34}$ JOHN C LUE, ${ }^{3}$ \\ D STEPHEN ROBINS, ${ }^{34}$ AND EFRAIM DUZMAN ${ }^{34}$
}

From 'Augenarzte-Gemeinschaftspraxis, Furth, West Germany; ${ }^{2}$ Ben-Gurion University, Beer Sheva, Israel; ${ }^{3}$ Department of Clinical Research, Allergan Pharmaceuticals, Inc.; and ${ }^{4}$ the University of California, Irvine, California, USA

SUMMARY Data for the first 12 months are reported for an ongoing, multicentre, clinical study comparing the long-term, ocular hypotensive efficacy and safety of topical levobunolol $(0 \cdot 5 \%$ and $1 \%)$ and timolol $(0 \cdot 5 \%)$. This study was a double-masked trial testing 88 patients with chronic open angle glaucoma or ocular hypertension. During the 12-month period drops were instilled twice daily into both eyes after a washout of prestudy ocular hypotensive medication. The effect of the three treatments in reducing intraocular pressure (IOP) was similar. Mean IOP reductions over the 12 months averaged $7.2 \mathrm{mmHg}$ for the $0.5 \%$ levobunolol group, $6.2 \mathrm{mmHg}$ for the $1 \%$ levobunolol group, and $6.0 \mathrm{mmHg}$ for the timolol group. Decreases in mean heart rate of up to 5 beats per minute were observed in the $0.5 \%$ levobunolol group, up to 8 beats per minute in the $1 \%$ levobunolol group, and up to 4 beats per minute in the timolol group. Several patients were removed from the study owing to side effects possibly related to levobunolol treatment.

Several short-term studies conducted to investigate the ocular hypotensive effect of various concentrations of topical levobunolol, a non-cardioselective beta-adrenergic blocking agent, have indicated that a maximal pressure reducing effect occurs with the $0.5 \%$ and $1 \%$ concentrations. ${ }^{2}$ Further comparison testing with the levobunolol vehicle over a threemonth time period has confirmed the sustained ocular hypotensive effect produced by these two concentrations of levobunolol over a longer time period. ${ }^{3}$

Because of the progressive nature of glaucoma and the possibility of long-term drift occurring with continued use of topical beta-adrenergic blocking agents $^{45}$ it is particularly important to assess longterm drug effect when evaluating these drugs. Therefore the present study, a parallel, double-masked clinical trial, was designed to test the efficacy and safety of $0.5 \%$ and $1 \%$ levobunolol compared with $0.5 \%$ timolol in patients with chronic open-angle glaucoma (COAG) or ocular hypertension (OHT) for a period of one year. As most of the patients participating in the study had successfully controlled

Correspondence to Dr Gary D Novak, Allergan Pharmaceuticals Inc., 2525 Dupont Drive, Irvine, California 92715, USA. intraocular pressure (IOP) while receiving study treatments, the study was extended for a second year and is still continuing. We report here the results of the first year of treatment.

\section{Patients and methods}

Before being entered in the trial the patients were examined to determine their suitability for it. All patients participating in the study were required to have COAG or OHT with an untreated intraocular pressure of $23 \mathrm{mmHg}$ or higher in each eye and none of the following conditions: (1) known contraindications to systemic or topical use of B-blocking agents; (2) use of adrenergic-augmenting psychotropic drugs; (3) use of topical or systemic corticosteroids; (4) severe diabetes requiring changes in insulin dosage; (5) pregnancy, expected pregnancy, or lactation; (6) aphakia, chronic ocular inflammation, or any corneal abnormalities preventing reliable applanation tonometry; (7) severe COAG uncontrolled by concomitant administration of two or more antiglaucoma drugs; (8) inability to tolerate washout of prestudy antiglaucoma medications; (9) contact lens wear during the study. 
Table 1 Examination variables and study schedule

\begin{tabular}{|c|c|c|c|c|c|c|c|}
\hline $\begin{array}{l}\text { Study } \\
\text { period }\end{array}$ & $\begin{array}{l}\text { Patient } \\
\text { history }\end{array}$ & $I O P$ & $\begin{array}{l}\text { Visual } \\
\text { field }\end{array}$ & $\begin{array}{l}\text { Visual } \\
\text { acuity }\end{array}$ & $\begin{array}{l}\text { Pupil } \\
\text { size }\end{array}$ & $\begin{array}{l}\text { Corneal } \\
\text { sensitivity }\end{array}$ & $\begin{array}{l}\text { Schirmer } \\
\text { test }\end{array}$ \\
\hline Prestudy & $\mathrm{X}$ & $\mathrm{X}$ & $\mathrm{X}$ & $\mathrm{X}$ & & & \\
\hline $\begin{array}{l}\text { Day } 1 \\
\quad \text { (baseline) }\end{array}$ & & $\mathrm{X}$ & & $X$ & $X$ & $\mathrm{X}$ & $\mathrm{X}$ \\
\hline Day 4 & & $\mathrm{X}$ & & $\mathrm{X}$ & $\mathrm{X}$ & $\mathrm{X}$ & \\
\hline Week 1 & & $\mathrm{X}$ & & $\mathbf{X}$ & $\mathrm{X}$ & $\mathrm{X}$ & \\
\hline Week 2 & & $\mathrm{X}$ & & $\mathrm{X}$ & $\mathrm{X}$ & $\mathrm{X}$ & \\
\hline Week 3 & & $\mathrm{X}$ & & $\mathrm{X}$ & $\mathrm{X}$ & $\mathrm{X}$ & \\
\hline Week 4 & & $\mathrm{X}$ & & $\mathrm{X}$ & $\mathrm{X}$ & $\mathrm{x}$ & $\mathrm{X}$ \\
\hline Week 6 & & $\mathrm{x}$ & & $\mathrm{X}$ & $\mathrm{X}$ & $\mathrm{X}$ & \\
\hline Week 8 & & $\mathrm{x}$ & & $\mathrm{X}$ & $\mathrm{X}$ & $\mathrm{x}$ & \\
\hline Week 10 & & $x$ & & $\mathrm{X}$ & $x$ & $x$ & \\
\hline Week 12 & & $x$ & & $X$ & $\mathrm{X}$ & $\mathrm{x}$ & $\mathrm{X}$ \\
\hline Week 16 & & $\mathrm{X}$ & & $\mathrm{X}$ & $\mathrm{X}$ & $\mathrm{X}$ & \\
\hline Week 20 & & $\mathrm{X}$ & & $\mathbf{X}$ & $\mathrm{X}$ & $\mathrm{X}$ & \\
\hline Week 24 & & $\mathrm{X}$ & $\mathrm{X}$ & $\mathrm{X}$ & $\mathrm{X}$ & $\mathrm{x}$ & $\mathrm{X}$ \\
\hline Week 32 & & $\mathrm{X}$ & & $\mathbf{X}$ & $\mathbf{X}$ & $\mathrm{X}$ & \\
\hline Week 40 & & $x$ & & $\mathrm{X}$ & $\mathrm{X}$ & $\mathrm{x}$ & \\
\hline Week 48 & & $\mathrm{X}$ & $\mathrm{X}$ & $\mathrm{X}$ & $\mathrm{X}$ & $\mathrm{X}$ & $\mathrm{X}$ \\
\hline
\end{tabular}

$\mathrm{CBC}=$ complete blood count.

After fulfilling these conditions the participating patients signed consent forms and underwent a washout period of prestudy antiglaucoma medication. This washout period lasted two days for pilocarpine, three days for carbonic anhydrase inhibitors, and two weeks for epinephrine, dipivefrin, or timolol. After washout the patients were randomly assigned to one of the three treatment groups $(0.5 \%$ levobunolol, $1 \%$ levobunolol, or $0.5 \%$ timolol) and were instructed to instill a single drop of medication, whose nature was unknown to the physician or patient, into each eye at 9 am and $9 \mathrm{pm}$ daily for the 12-month study period.

Study variables listed in Table 1 were evaluated at baseline and at 15 return visits during the one-year study period. At return visits the IOP was measured prior to instillation of the morning medication. Applanation tonometry was used to measure IOP and the Schirmer tear test on anaesthetised eyes to measure tear production. Corneal sensitivity was measured by touching a wisp of cotton to the centre of the cornea and grading the blink response.

Table 2 Demographic data and diagnosis (number of patients in parentheses)

\begin{tabular}{|c|c|c|c|}
\hline Variable & $\begin{array}{l}0.5 \% \text { Levobunolol } \\
(\mathrm{n}=31)\end{array}$ & $\begin{array}{l}\text { I\% Levobunolol } \\
(\mathrm{n}=31)\end{array}$ & $\begin{array}{l}0.5 \% \text { Timolol } \\
(n=26)\end{array}$ \\
\hline \multicolumn{4}{|l|}{ Age } \\
\hline Mean & $59 \cdot 5$ & 59.9 & $64 \cdot 0$ \\
\hline SD & $10 \cdot 7$ & $10 \cdot 1$ & $10 \cdot 3$ \\
\hline Range & $42-76$ & $31-80$ & $45-87$ \\
\hline \multicolumn{4}{|l|}{ Sex } \\
\hline Male & 11 & 12 & 10 \\
\hline Female & 20 & 19 & 16 \\
\hline \multicolumn{4}{|l|}{ Race } \\
\hline Caucasian & 31 & 31 & 26 \\
\hline Non-Caucasian & 0 & 0 & 0 \\
\hline \multicolumn{4}{|l|}{ Iris colour } \\
\hline Blue & 3 & 14 & 9 \\
\hline Green & 11 & 6 & 9 \\
\hline Brown & 17 & 10 & 8 \\
\hline Black & 0 & 1 & 0 \\
\hline \multicolumn{4}{|l|}{ Diagnosis } \\
\hline OHT & 20 & 24 & 17 \\
\hline COAG & 11 & 7 & 9 \\
\hline
\end{tabular}




\begin{tabular}{|c|c|c|c|c|c|c|}
\hline $\begin{array}{l}\text { Biomicro- } \\
\text { scopic } \\
\text { eye exam. }\end{array}$ & $\begin{array}{l}\text { Ophthalmo- } \\
\text { scopic } \\
\text { eye exam. }\end{array}$ & $\begin{array}{l}\text { Heart } \\
\text { rate }\end{array}$ & $\begin{array}{l}\text { Blood pressure, } \\
\text { systolicl } \\
\text { dioastolic }\end{array}$ & $\begin{array}{l}\text { Auscultation } \\
\text { of heart } \\
\text { and lungs }\end{array}$ & $E C G$ & $\begin{array}{l}C B C l \\
\text { blood } \\
\text { chemistry }\end{array}$ \\
\hline $\mathrm{X}$ & $X$ & $\mathrm{X}$ & $\mathrm{X}$ & $\mathrm{X}$ & $\mathrm{X}$ & $X$ \\
\hline $\mathrm{X}$ & $\mathrm{X}$ & $\mathrm{x}$ & $\mathrm{X}$ & & & \\
\hline $\mathrm{X}$ & $\mathrm{X}$ & $\mathrm{x}$ & $\mathrm{X}$ & & & \\
\hline $\mathrm{X}$ & $\mathrm{X}$ & $\mathrm{X}$ & $\mathrm{X}$ & & & \\
\hline $\mathrm{X}$ & $\mathrm{X}$ & $\mathrm{X}$ & $\mathrm{X}$ & & & \\
\hline $\mathrm{X}$ & $\mathrm{X}$ & $\mathrm{X}$ & $X$ & & & \\
\hline$X$ & $X$ & $X$ & $\mathrm{X}$ & $\mathrm{X}$ & & $\mathrm{X}$ \\
\hline $\mathrm{X}$ & $\mathrm{X}$ & $\mathrm{x}$ & $\mathrm{x}$ & & & \\
\hline $\mathrm{X}$ & $\mathrm{X}$ & $\mathrm{X}$ & $\mathrm{x}$ & & & \\
\hline $\mathrm{X}$ & $\mathrm{X}$ & $\mathrm{X}$ & $\mathrm{X}$ & & & \\
\hline $\mathrm{X}$ & $\mathrm{X}$ & $\mathrm{X}$ & $\mathrm{X}$ & $\mathbf{X}$ & & $\mathbf{X}$ \\
\hline $\mathbf{X}$ & $x$ & $\mathrm{X}$ & $\mathrm{X}$ & & & \\
\hline $\mathrm{X}$ & - $\mathrm{X}$ & $\mathrm{X}$ & $X$ & & & \\
\hline $\mathrm{X}$ & $\mathbf{X}$ & $\mathrm{X}$ & $\mathrm{X}$ & $\mathbf{X}$ & $X$ & $\mathbf{X}$ \\
\hline $\mathrm{X}$ & $\mathrm{X}$ & $\mathrm{X}$ & $\mathrm{X}$ & & & \\
\hline $\mathrm{X}$ & $\mathrm{X}$ & $\mathrm{X}$ & $\mathrm{X}$ & & & \\
\hline $\mathbf{X}$ & $\mathrm{X}$ & $\mathrm{X}$ & $\mathrm{X}$ & $\mathbf{X}$ & $X$ & $X$ \\
\hline
\end{tabular}

Patients could be removed from the study for administrative reasons not associated with the treatment, or their treatment could be terminated owing to adverse reactions to the test treatments or because of inadequately controlled IOP. In patients receiving prestudy antiglaucoma drugs an uncontrolled IOP was defined as an IOP that was significantly greater ( $>5 \mathrm{mmHg}$ ) than prewashout values at two consecutive visits. In patients receiving no prestudy antiglaucoma drugs an uncontrolled IOP was defined as an IOP that was not decreased by at least $20 \%$ of the pretreatment value at two consecutive visits.

A two-way analysis of variance (ANOVA) ${ }^{6}$ was used to compare mean values at baseline and mean change from baseline at each return visit among the treatment groups for the following variables: age, IOP, pupil size, Schirmer tear test results, heart rate, and systolic and diastolic blood pressure. Right and left eye values were averaged for analysis of IOP, pupil size, and Schirmer tear test results. An ANOVA model for repeated measures' was used to compare treatment effects for these variables (except age) over the entire study period. Race, sex, iris colour, and prestudy medical and ophthalmololgical histories were analysed by the generalised CochranMantel-Haenzel procedure. ${ }^{*}$ All other variables evaluated were analysed by descriptive statistical methods, namely, counts, means, frequencies. For all analyses a $p$ value $\leqslant 0.05$ was considered statistically significant.

\section{Results}

DEMOGRAPHICS AND PATIENTS' HISTORIES Of the 88 patients participating in the study 31 were in each of the levobunolol groups and 26 were in the timolol group. The distribution of patients with regard to age, sex, race, iris colour, and disease diagnosis is presented in Table 2. No significant differences were observed among the treatment groups in any demographic or medical history variables evaluated except cardiovascular disorders. The timolol group had a significantly greater proportion of patients with diagnosed cardiovascular disorders than either levobunolol group. No statistically significant differences were observed among the treatment groups at baseline for any of the efficacy or safety variables analysed.

\section{PATIENT STATUS}

The number of patients whose IOP was controlled during the study is shown in Table 3 . Twenty-three patients in the $0.5 \%$ levobunolol group, 22 patients in the $1 \%$ levobunolol group, and 24 patients in the timolol group are continuing in the study. Five patients in the $0.5 \%$ levobunolol group, six patients in the $1 \%$ levobunolol group, and two patients in the timolol group were removed from the study because of inadequately controlled IOP, and five patients were removed for side effects thought by the investigator to be related to levobunolol treatment. Two patients, one treated with $0.5 \%$ levobunolol and one with $1 \%$ levobunolol, showed signs of ocular irritation (blepharitis, conjunctival erythema). In most cases of ocular irritation it was possible to challenge the patient with both the vehicle and a repeat exposure to the drug. In these cases ocular irritation recurred only with exposure to the drug. One patient treated with $1 \%$ levobunolol reported a subjective decrease in visual acuity which could not be con- 
Table 3 Status of patients at the end of the 12-month study period (number of patients in parentheses)

\begin{tabular}{lllr}
\hline Status & $\begin{array}{l}0.5 \% \text { Levobunolol } \\
(\mathrm{n}=31)\end{array}$ & $\begin{array}{l}1 \% \text { Levobunolol } \\
(\mathrm{n}=31)\end{array}$ & $\begin{array}{l}0.5 \% \text { Timolol } \\
(\mathrm{n}=26)\end{array}$ \\
\hline $\begin{array}{l}\text { Ongoing/adequately controlled IOP } \\
\begin{array}{l}\text { Discontinued from study* } \\
\text { Removed from study: }\end{array}\end{array}$ & 23 & 22 \\
$\begin{array}{l}\text { lack of IOP control } \\
\text { side effects }\end{array}$ & 0 & 1 & 0 \\
& 5 & 6 & 24 \\
\end{tabular}

* For reasons unrelated to the test treatments.

firmed by the investigator. One patient treated with $0.5 \%$ levobunolol complained of headaches, and another patient also treated with $0.5 \%$ levobunolol complained of heartburn and diarrhoea.

\section{EFFICACY}

The ocular hypotensive effect of the three treatments was similar: after an immediate drop in IOP at the first return visit, IOP reductions were sustained throughout the one-year trial (Fig. 1). Mean reductions in IOP from baseline ranged from 5.9 to 8.1 $\mathrm{mmHg}$ in the $0.5 \%$ levobunolol group, from 5.2 to $7.1 \mathrm{mmHg}$ in the $1 \%$ levobunolol group, and from 4.7 to $6.9 \mathrm{mmHg}$ in the timolol group. Significant differences among the groups in the magnitude of IOP reductions were seen only on the return visit at week 24 , when the $0.5 \%$ levobunolol group had a significantly greater reduction in IOP than the timolol group (Table 4).

\section{SAFETY}

The graphical representation of mean heart rate over the one-year study period showed similar decreases with each of the treatments (Fig. 2). Mean decreases of up to $5 \mathrm{bpm}$ were observed within the $0.5 \%$ levobunolol group, up to $8 \mathrm{bpm}$ within the $1 \%$ levobunolol group, and up to $4 \mathrm{bpm}$ within the timolol group. Although some individuals in each of the treatment groups had clinically significant decreases in heart rate at some of the return visits, none had a heart rate less than 55 beats per minute or a diagnosis of sinus bradycardia on electrocardiographic (ECG) examination.

Both levobunolol and timolol appeared to have little effect on systolic and diastolic blood pressure (Fig. 3). In the three treatment groups overall decreases in mean systolic blood pressure ranged from 3 to $4 \mathrm{mmHg}$ and overall decreases in diastolic blood pressure from 1 to $5 \mathrm{mmHg}$.

Table 4 Mean intraocular pressure changes from baseline $(\mathrm{mmHg})$

\begin{tabular}{|c|c|c|c|c|c|c|c|}
\hline \multirow{2}{*}{$\begin{array}{l}\text { Study } \\
\text { period }\end{array}$} & \multicolumn{2}{|c|}{$0.5 \%$ Levobunolol } & \multicolumn{2}{|c|}{$1 \%$ Levobunolol } & \multicolumn{2}{|c|}{$0.5 \%$ Timolol } & \multirow{2}{*}{$\begin{array}{l}\text { Among-group } \\
p \text { values }\end{array}$} \\
\hline & $n$ & Mean SD & $n$ & Mean SD & $n$ & Mean SD & \\
\hline $\begin{array}{l}\text { Day } 1 \\
\quad \text { (baseline) }\end{array}$ & 31 & $27 \cdot 9 \pm 5 \cdot 5$ & 31 & $27 \cdot 0 \pm 3 \cdot 7$ & 26 & $26 \cdot 4 \pm 2 \cdot 8$ & NS \\
\hline $\begin{array}{l}\text { Day } 4 \\
\text { Week } 1 \\
\text { Week } 2 \\
\text { Week } 3 \\
\text { Week } 4 \\
\text { Week } 6 \\
\text { Week } 8 \\
\text { Week } 10 \\
\text { Week } 12 \\
\text { Week } 16 \\
\text { Week } 20 \\
\text { Week } 24 \\
\text { Week } 32 \\
\text { Week 40 } \\
\text { Week } 48\end{array}$ & $\begin{array}{l}28 \\
27 \\
28 \\
26 \\
26 \\
23 \\
23 \\
23 \\
21 \\
21 \\
21 \\
20 \\
19 \\
17 \\
15\end{array}$ & $\begin{array}{r}-8.1^{*} \pm 4.4 \\
7.7 \pm 3.3 \\
-7.4 \pm 3.4 \\
-7.0 \pm 3.4 \\
-7.3 \pm 3.5 \\
-7.2 \pm 3.0 \\
-6.9 \pm 3.6 \\
-6.9 \pm 3.8 \\
-6.9 \pm 3.4 \\
7.5 \pm 2.7 \\
-6.8 \pm 2.5 \\
-7.3 \pm 2.4 \\
-6.5 \pm 2.5 \\
-5.9 \pm 2.3 \\
-6.0 \pm 2.5\end{array}$ & $\begin{array}{l}31 \\
27 \\
29 \\
28 \\
25 \\
23 \\
24 \\
21 \\
21 \\
24 \\
23 \\
20 \\
19 \\
18 \\
17\end{array}$ & $\begin{array}{l}-6 \cdot 9 \pm 3 \cdot 6 \\
-6 \cdot 5 \pm 2 \cdot 8 \\
-6 \cdot 7 \pm 3 \cdot 4 \\
-7 \cdot 1 \pm 3 \cdot 4 \\
-6 \cdot 5 \pm 3 \cdot 0 \\
-6 \cdot 2 \pm 1 \cdot 9 \\
-6 \cdot 3 \pm 2 \cdot 3 \\
-6 \cdot 3 \pm 2 \cdot 1 \\
-6 \cdot 4 \pm 1 \cdot 7 \\
-6 \cdot 9 \pm 2 \cdot 9 \\
-5 \cdot 9 \pm 2 \cdot 0 \\
-6 \cdot 2 \pm 2 \cdot 5 \\
-5 \cdot 3 \pm 2 \cdot 5 \\
-5 \cdot 4 \pm 1 \cdot 9 \\
-5 \cdot 2 \pm 1 \cdot 6\end{array}$ & $\begin{array}{l}26 \\
26 \\
24 \\
24 \\
25 \\
24 \\
25 \\
24 \\
25 \\
24 \\
22 \\
22 \\
20 \\
17 \\
15\end{array}$ & $\begin{array}{l}-6 \cdot 9 \pm 2 \cdot 9 \\
-5 \cdot 7 \pm 3 \cdot 8 \\
-6 \cdot 0 \pm 2 \cdot 6 \\
-6 \cdot 3 \pm 3 \cdot 2 \\
-6 \cdot 7 \pm 3 \cdot 1 \\
-6 \cdot 7 \pm 3 \cdot 0 \\
-6 \cdot 3 \pm 2 \cdot 9 \\
-6 \cdot 5 \pm 3 \cdot 1 \\
-6 \cdot 4 \pm 3 \cdot 0 \\
-6 \cdot 5 \pm 2 \cdot 6 \\
-6 \cdot 1 \pm 1 \cdot 9 \\
-5 \cdot 6 \pm 2 \cdot 1 \\
-5 \cdot 4 \pm 2 \cdot 3 \\
-5 \cdot 3 \pm 1 \cdot 7 \\
-4 \cdot 7 \pm 1 \cdot 7\end{array}$ & $\begin{array}{l}\text { NS } \\
\text { NS } \\
\text { NS } \\
\text { NS } \\
\text { NS } \\
\text { NS } \\
\text { NS } \\
\text { NS } \\
\text { NS } \\
\text { NS } \\
\text { NS } \\
0 \cdot 027 \dagger \\
\text { NS } \\
\text { NS } \\
\text { NS }\end{array}$ \\
\hline $\begin{array}{l}\text { Overall } \\
\text { mean change }\end{array}$ & & $-7 \cdot 2$ & & $-6 \cdot 2$ & & $-6 \cdot 0$ & NS \\
\hline
\end{tabular}

* All treatment groups showed significant within-group decreases from baseline at each follow-up day ( $\mathrm{p} \leqslant 0 \cdot 001)$.

NS= not significant.

† When among-group comparisons were made on day 169 , mean decreases in the $0 \cdot 5 \%$ levobunolol group were significantly greater than the timolol group. 


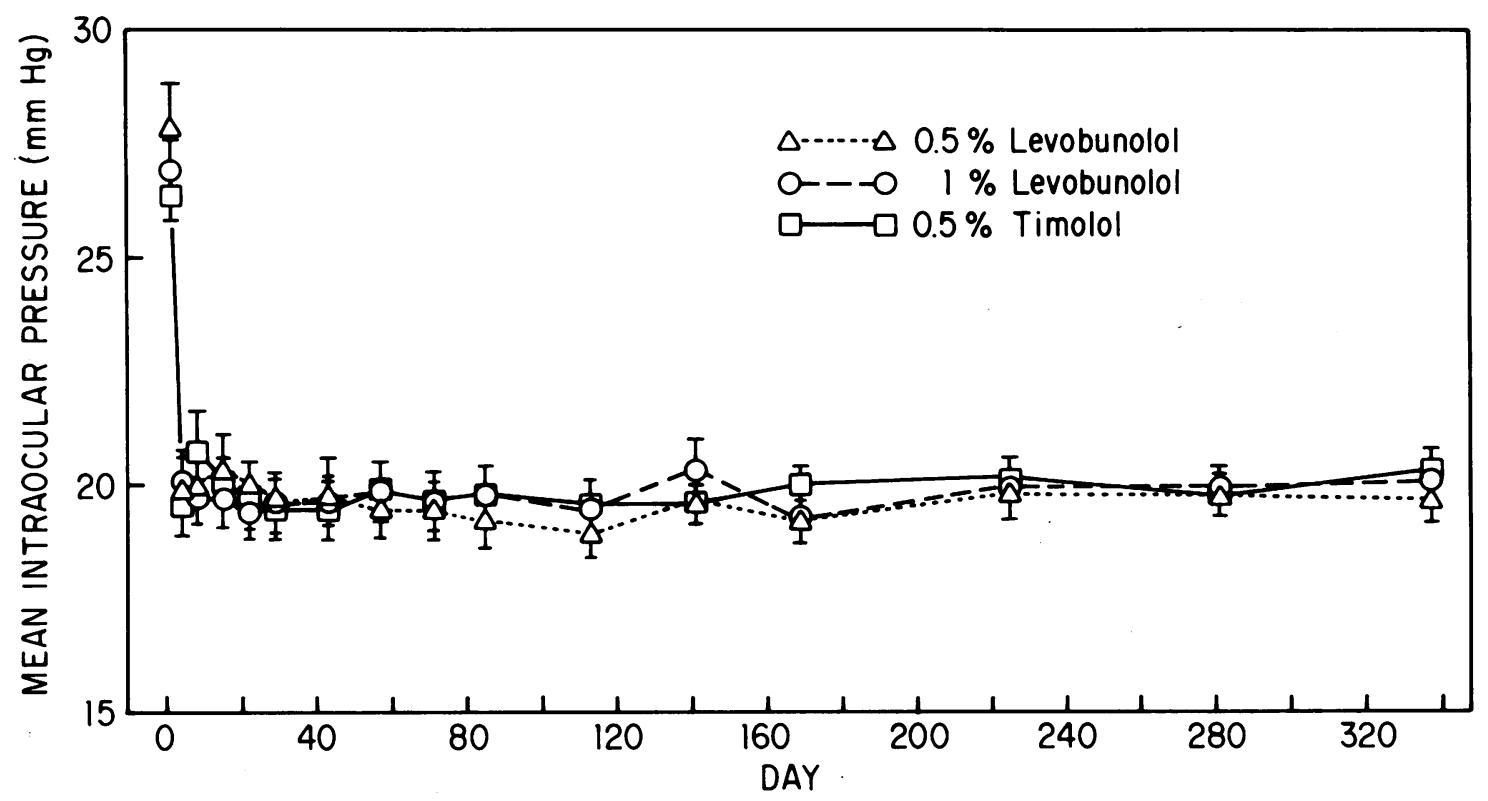

Fig. 1 Mean IOP values after topical treatment with $0 \cdot 5 \%$ levobunolol, $1 \%$ levobunolol, or $0.5 \%$ timolol.

Few changes from baseline values were seen in visual acuity, pupil size, cup-disc ratio, corneal sensitivity, Schirmer tear test results, or biomicroscopic and ophthalmoscopic findings. Observed changes were mild and similarly distributed between levobunolol and timolol treatment groups. Only one patient treated with $1 \%$ levobunolol complained of burning and stinging, and this was at only one visit. No changes in visual fields occurred during the study. No systemic findings of note were observed during auscultation of the heart and lungs, ECG examination, or blood analysis.

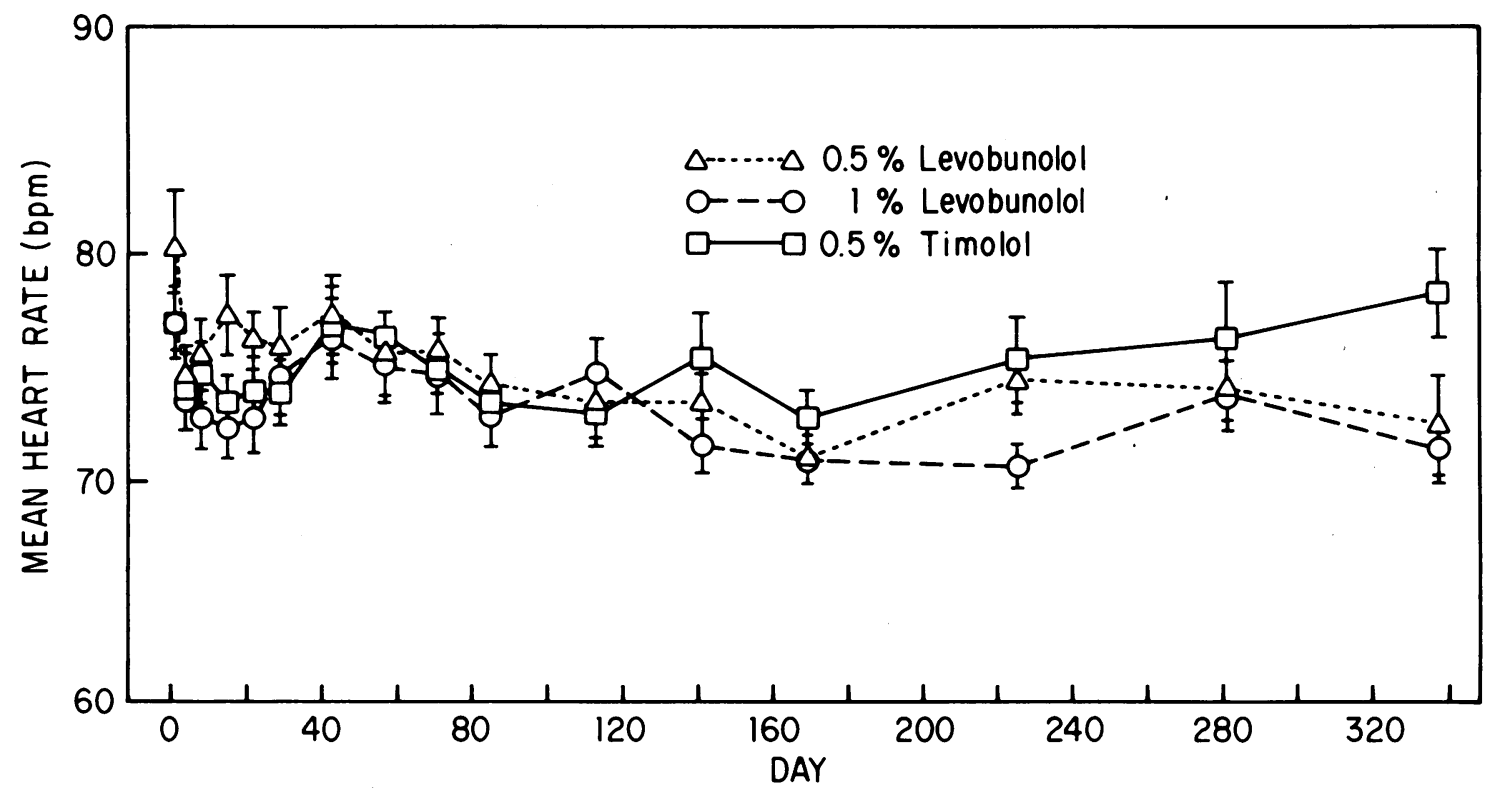

Fig. 2 Mean heart rate values after topical treatment with $0 \cdot 5 \%$ levobunolol, $1 \%$ levobunolol, or $0 \cdot 5 \%$ timolol. 


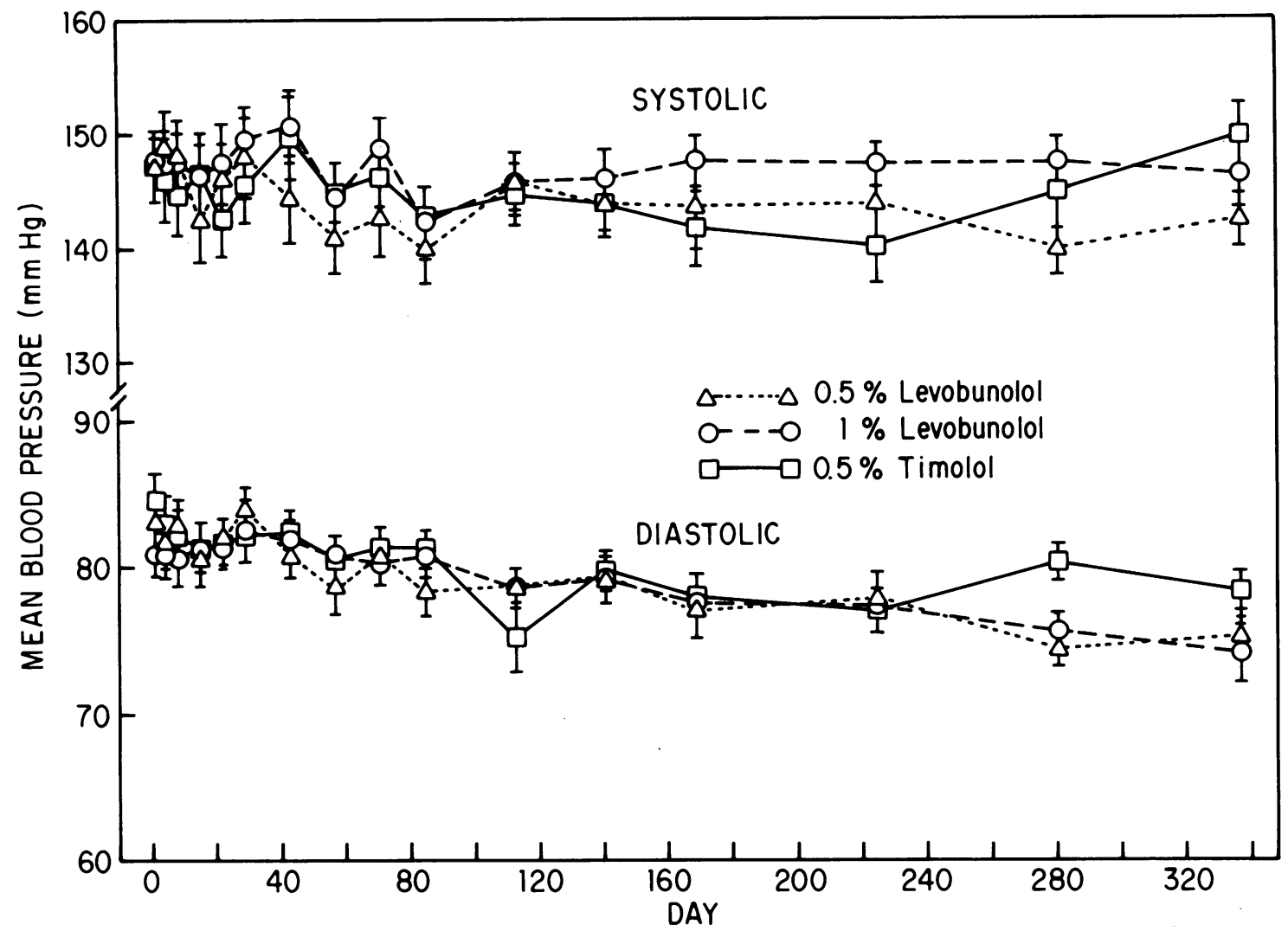

Fig. 3 Systolic and diastolic blood pressure values after topical treatment with $0.5 \%$ levobunolol, $1 \%$ levobunolol, or $0.5 \%$ timolol.

\section{Discussion}

The results from this year-long clinical trial confirm the long-term occular hypotensive efficacy of levobunolol in treating elevated IOP. Topically applied levobunolol in concentrations of $0.5 \%$ and $1 \%$ produced a significant and sustained reduction in IOP in patients with chronic open-angle glaucoma or ocular hypertension. The IOP reduction produced by levobunolol was not significantly different from that produced by timolol, nor was the number of subjects removed from the study for failure of treatment significantly different among the groups.

Treatment with levobunolol was associated with few ocular side effects. No significant changes in tear production, as measured by the Schirmer test, nor in corneal sensitivity, as measured by the blink response, were noted. In this large multisite longterm study it was not feasible to use an anaesthesiometer to measure corneal sensitivity more precisely. Changes in mean heart rate and blood pressure occurring with both levobunolol treatments were not of clinical importance.
A greater number of levobunolol treated patients than timolol treated patients were removed from this study as a result of adverse experiences attributed to the test medication. However, although the signs and symptoms resulting in the removal of patients from the study were seen only in levobunolol treated patients, blepharitis, ${ }^{9}$ conjunctival erythema, ${ }^{9}$ headaches, ${ }^{11}$ and diarrhoea" have all been reported with topical timolol usage.

In the patient complaining of 'non-specific blurring of central vision' no change in refraction was detectable.

Although long-term drift has been associated with timolol treatment, ${ }^{34}$ data from this study do not suggest a significant drifting of IOP over the one-year period with either timolol or levobunolol treatment. It appears that levobunolol will be a beneficial and long-effective addition to the currently available treatments for glaucoma and ocular hypertension.

The authors gratefully acknowledge the statistical assistance of Kuan Kuan Chen, the technical assistance of Amy Crawford, and the editorial assistance of Mary-Jane Branin. 


\section{References}

1 Duzman E, Ober M, Scharrer A, Leopold IH. A clinical evaluation of the effects of topically applied levobunolol and timolol on increased intraocular pressure. Am J Ophthalmol 1982; 94: 318-27.

2 Partamian LG, Kass MA, Gordon M. A dose-response study of the effect of levobunolol on ocular hypertension. Am J Ophthalmol 1983; 95: 229-32.

3 Keates E, Bensinger R, Novack G, Robins DS, Duzman E. A three-month efficacy study in the treatment of glaucoma. VIIth Congress of the European Society of Ophthalmology Abstracts Book. Helsinki: European Society of Ophthalmology, 1984: 316.

4 Mills KB. Blind randomised non-crossover long-term trial comparing topical timolol $0.25 \%$ with timolol $0.5 \%$ in the treatment of simple chronic glaucoma. Br J Ophthalmol 1983; 67: 216-9.

5 Steinert RF, Thomas JV, Boger WP. Long-term drift and continued efficacy after multiyear timolol therapy. Arch Ophthalmol 1981; 99: 100-3.

6 Afifi A, Azen SP. Statistical analysis, a computer oriented approach. New York: Academic Press, 1972: 162-9.

7 Winer BJ. Statistical principles in experimental design. New York: McGraw-Hill, 1971: 514-38.

8 Landis JR, Cooper M, Martinez M, Koch GG. An application of the generalized Cochran-Mantel-Hacnzel procedure to multicenter clinical trial data. In: Proceedings of the Pharmaceutical Manufacturers Association Meeting. Arlington: Pharmaccutical Manufacturers Association, 1978: 1-18.

9 Van Buskirk EM. Adverse reactions from timolol administration. Ophthalmology (Rochester) 1980; 87: 447-50.

10 Fraunfelder FT, Meyer M, eds. Seventh annual technical report of the national registry of drug-induced ocular side effects (contract no. 223-82-3012), September 1982 to June 1983. Portland: Department of Ophthalmology, Oregon Health Sciences University, 1983. 